\title{
Candidate Reagents and Procedures for the Dissolution of Hanford Site Single-Shell Tank Sludges
}

Prepared for the U.S. Department of Energy Office of Environmental Restoration and Waste Management

\section{(2) Westinghouse \\ (V) Hanford Company Richland, Washington}

Hanford Operations and Engineering Contractor for the

U.S. Department of Energy under Contract DE-AC06-87RL10930 


\section{LEGAL DISCLAIMER}

This report was prepared as an account of work sponsored by an agency of the United States Government. Neither the United States Government nor any agency thereof, nor any of their employees, nor any of their contractors, subcontractors or their employoes, makes any warranty, express or implied, or assumes any legal liability or responsibility for the accuracy, completeness, or any third party's use or the results of such use of any information, apparatus, product, or process disclosed, or represents that its use would not infringe privately owned rights. Reference herein to any specific commercial product, process, or service by trade name trademark, manufacturer, or otherwise, does not necessarily constitute or imply its endorsement, recommendation, or favoring by the United States Government or any agency thereof or its contractors or subcontractors. The views and opinions of authors expressed herein do not necessarily state or reflect those of the United States Government or any agency thereof.

This report has been reproduced from the best available copy. Available in paper copy and microfiche.

Avallable to the U.S. Department of Energy and its contractors from

Office of Scientific and Technical Information

P.O. Box 62

Oak Ridge. TN 3783

(615) 576.8401

Available to the public from the U.S. Department of Comrierce National Technical Information Service

5285 Port Royal Road

Springfield, VA 22161

(703) 487.4650

Printed in the United Stutes of America 


\section{Candidate Reagents and Procedures for the Dissolution of Hanford Site Single-Shell Tank Sludges}

W. W. Schulz

M. J. Kupfer

Date Published

October 1991

Prepared for the U.S. Department of Energy Office of Environmental Restoration and Waste Management

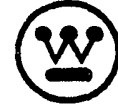

Westinghouse

Hanford Company Richland, Washington 99352

Hanford Operations and Engineering Contractor for the

U.S. Department of Energy under Contract DE-AC06-87RL10930 
WHC-EP-0451

This page intentionally left blank. 
WHC-EP-0451

\title{
CANDIDATE REAGENTS AND PROCEDURES FOR DISSOLUTION OF HANFORD SITE SINGLE-SHELL TANK SLIJDGES
}

W. W. Schulz

M. J. Kupfer

\begin{abstract}
This report discusses incentives and potentially suitable aqueous and nonaqueous methods for the preparation of aqueous nitric acid solutions from various radioactive solids present in Hanford Site single-shell tanks. $A$ recommended sequence of reagents to test and use for dissolution of each class of single-shell tank waste sludge is provided.
\end{abstract}


WHC-EP-0451

This page intentionally left blank. 


\section{CONTENTS}

1.0 INTRODUCTION AND BACKGROUND . . . . . . . . . . . . . . . . . 1-1

2.0 GUIDING PRECEPTS AND RECOMMENDATIONS . . . . . . . . . . . 2-1

2.1 PRECEPTS ...................... . . 2-1

2.2 RECOMMENDATIONS ................. . . 2-1

3.0 TYPES AND COMPOSITIONS OF HANFORD SITE SLUDGES . . . . . . . . . . 3-1

4.0 SLUDGE SOLUBILIZATION APPROACHES . . . . . . . . . . . . . 4-1

5.0 AQUEOUS LEACHING REAGENTS/PROCEDURES . . . . . . . . . . . . . . . . 5-1

5.1 CANDIDATE SLUDGE LEACHANTS . . . . . . . . . . . . . . . . 5-1

5.1.1 Sodium Hydroxide . . . . . . . . . . . . . . . . 5-1

5.1.2 Nitric Acid . . . . . . . . . . . . . . . . . 5-1

5.1.3 Nitric Acid-0xalic Acid . . . . . . . . . . . . . . 5-1

5.1.4 Thermally Unstable Complexants-Reducing Agent . . . . 5-1

5.1.5 Nitric Acid-Fluoride . . . . . . . . . . . . . . 5-2

5.1.6 Concentrated $\mathrm{H}_{2} \mathrm{SO}_{4}$ or $\mathrm{H}_{3} \mathrm{PO}_{4}$. . . . . . . . . . . . . . . 5-3

5.1 .7 others................ . . 5-3

5.2 RECOMMENDED REAGENTS AND PROCEDURES . . . . . . . . . . . 5-4

6.0 FUSION REAGENTS AND PROCEDURES . . . . . . . . . . . . . . 6-1

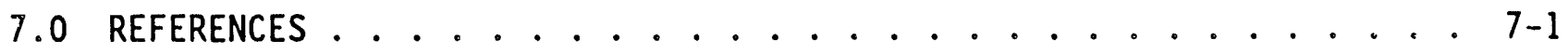
APPENDIXES

A. REVIEW OF EXISTING SLUDGE DISSOLUTION EXPERIMENTAL DATA . . . A-1

B. REAGENTS TESTED FOR DISSOLUTION OF CESIUM ZINC FERROCYANIDE

PRECIPITATES ...................... . . B-1 
WHC-EP-0451

\section{LIST OF FIGURES}

1-1 Sludge Dissolution Approaches .............. . . 4-2

\section{LIST OF TABLES}

3-1 Types and Composition of Hanford Site Tank Sludges . . . . . . . 3-2

3-2 Select Single-Shell Tanks Miscellaneous Waste . . . . . . . . 3-3

5-1 Proposed Sequential Leaching Schemes For Hanford Site Tank Sludges--Prel iminary Recommendations ...... . . . . 5-5

6-1 Potential Fluxes For Solubilizing Hanford Site Tank Sludges . . . . 6-1 
WHC-EP-0451

\section{LIST OF TERMS}

DOE

DST

LLW

PUREX

REDOX

SST

TRU

TRUEX

TUCS
U.S. Department of Energy double-shell tank low-level waste

Plutonium-Uranium Extraction (Plant) reduction oxidacion

single-shell tank

transuranic

transuranium extraction

thermally unstable complexants 
WHC-EP-0451

This page intentionally left blank. 
WHC-EP-0451

\section{CANDIDATE REAGENTS AND PROCEDURES FOR DISSOLUTION OF HANFORD SITE SINGLE-SHELL TANK SLUDGES}

\subsection{INTRODUCTION AND BACKGROUND}

At least some of the waste in the 149 single-shell tanks (SST) at the U.S. Department of Energy (DOE) Hanford Site will be retrieved, treated, and disposed of. This action is considered likely given today's political, regulatory, and environmental focus, both nationally and in washington state.

It is anticipated that retrieved SST waste will be separated into a soluble and an insoluble (sludge) fraction. The soluble fraction, a highly alkaline solution, should be suitable for grouting and land disposal after removal of some radionuclides (e.g., ${ }^{90} \mathrm{Sr},{ }^{89} \mathrm{Tc}$, and ${ }^{137} \mathrm{Cs}$ ) and hazardous chemicals.

Several previous engineering studies have addressed chemical treatment of the sludge fraction. These studies have resulted in one important conclusion (i.e., there are large economic incentives to chemically treat SST sludge to substantially reduce the material mass that must be vitrified and disposed of).

These engineering studies have also identified the critical sludge treatment step to be dissolution of the sludge to solubilize contained transuranic (TRU) waste elements and other radionuclides, particularly ${ }^{90} \mathrm{Sr}$, in an acidic medium suitable for downstream radionuclide removal operations. Economically, the ideal sludge dissolution procedure would solubilize all the TRU and ${ }^{90} \mathrm{Sr}$ values and, to the extent necessary, certain hazardous chemicals to ieave inert residues that would not require expensive vitrification and geologic disposal.

Although the importance of devising efficient and cost-effective siudge dissolution procedures has long been recognized, a concerted bench-scale effort to devise and test such procedures with actual solids representative of those in Hanford Site SSTs hias not been performed. Reagents that might be used, either individually or serially, to dissolve sludges include $\mathrm{HNO}_{3}$, $\mathrm{HNO}_{3}$-oxalic acid, and $\mathrm{HNO}_{3}-\mathrm{HF}$.

This report conso? idates and updates perspectives and recommendations concerning reagents and procedures for dissolving Hanford Site SST and selected double-shell tank (DST) sludges*. The principal objectives of this report are as follows.

1. Compile and review existing experimental data on dissolution of actual Hanford Site SST and DST sludges.

*Information concerning expected and/or projected dissolution behavior and properties of selected DST sludges is presented for completeness and because of the close similarity of some SST and DST sludges. 
2. Further inform Hanford Site engineers and scientists concerning the utility of combinations of thermally unstable complexants (TUCS) reagents and various reducing agents for dissolving SST and DST sludges. (This latter technology has recently been explored at the Argonne National Laboratory.)

3. Provide guidance in laying out a comprehensive experimental program to develop technology for dissolving all types of Hanford Site SST and DST sludges. 
WHC-EP-0451

\subsection{GUIDING PRECEPTS AND RECOMMENDATIONS}

\subsection{PRECEPTS}

The precepts below are assumed by the authors in evaluating methods for dissolution of DST and SST sludges.

1. It is not absolutely necessary to completely dissolve all sludges if residues contain acceptably low concentrations of TRU elements, ${ }^{90} \mathrm{Sr},{ }^{137} \mathrm{Cs}$, and other constituents to permit disposal as $10 \mathrm{w}-1$ evel weste (LLW)

2. It is highly desirable to develog reagents or procedures that can be used to maximize dissolution of all sludges to minimize or eliminate difficulties associated with sampling and analyzing undissolved solids for their content of TRU and othe: elements.

3. It is highly unlikely, because of the wide variations in sludge history and composition, that a single aqueous dissolvent can be found that will effectively treat all sludge types.

4. Although they present major engineering-scale difficulties, nonaqueous procedures (i.e., fusions) are likely to be effective in solubilizing intractable sludges $n r$ residues from previous aqueous leaching.

5. It is highiy unlikely, because of the wide variations in sludge history and composition, that a single flux can be found that will effectively treat all sludge types.

6. Flexibility should be provided in conceptual flowsheets for sludge dissolution to address the following: (1) processes that entail both aqueous leaching and high-temperature fusions, (2) suitable corrosion-resistant equipment for performing aqueous leachings and/or high-temperature fusions, (3) equipment and procedures for separation of leachants from residual solids, and (4) suitable equipment for taking representative samples of solid residues.

\subsection{RECOMMENDATIONS}

The recommendations for establishing a comprehensive experimental program for the solubilization of tank sludges are listed below.

1. Develop and execute a comprehensive dissolution plan for bench-scale sequential tests with actual water-washed tank sludges. The goal of 
this plan should be to determine practicable dissolution schemes that can be applied on a plant scale. This plan should address the following aspects:

a. Nature, hierarchy, volume, and composition of reagents to be employed with each sludge type*

b. Details (e.g., time, temperature) of each sequential dissolution step

c. Analytical procedures to measure the degree of dissolution accomplished with each reagent.

2. Develop and execute a plan for bench-scale high-temperature fusion t.ests with actual water-washed sludges. This plan should address the following aspects:

a. Applicability of $\mathrm{B}_{2} \mathrm{O}_{3}, \mathrm{KOH}$ (or $\mathrm{NaOH}$ ), and $\mathrm{Na}_{2} \mathrm{CO}_{3}$ fusions to solubilize all or part of each sludge type

b. Details (e.g., time, temperature, flux-to-sludge ratio) of each fusion

c. Procedures for dissolving fused melts in water or $\mathrm{HNO}_{3}$; special attention should be given to establish the stability of acidified solutions to the precipitation of silicic acid or other solids

d. Analytical procedures to measure the degree of dissolution accomplished in each fusion.

3. Provide preliminary engineering evaluations of promising aqueous dissolution and fusion procedures to guide bench-scale and pilot plant-scale tests.

*A recommended order of leachants to test, at least initially, with various types of sludge is discussed in Section 5.0 of this report. 


\subsection{TYPES AND COMPOSITIONS OF HANFORD SITE SLUDGES}

Various processes and operations performed over more than $35 \mathrm{yr}$ contributed to the presence of several types and amounts of sludge in Hanford Site SSTS and DSTs. Sludges resulted from the following operations.

1. Neutralization of high-level aqueous waste produced in irradiated fuel reprocessing operations [reduction oxidation (REDOX), plutonium-uranium extraction (PUREX), and bismuth phosphate $\left.\left(\mathrm{BiPO}_{4}\right)\right]$ processes.

2. Dissolution of $\mathrm{Al}-\mathrm{Si}$ bonded aluminum cladding in $\mathrm{NaOH}-\mathrm{NaNO}_{3}$ solutions; the $\mathrm{Al}-\mathrm{Si}$ bonding material largely remained undissolved.

3. Precipitation of $\mathrm{Ni}_{2} \mathrm{Fe}(\mathrm{CN})_{6}$ in certain SSTs.

4. Precipitation of aluminosilicates, carbonates, and other inorganic compounds from alkaline waste solutions.

5. Neutralization of acidic waste produced in Plutonium Finishing Plant and T Plant operations.

6. Neutralization of the Zirflex process decladding solution.

7. Addition of miscellaneous solids (e.g., diatomaceous earth and/or cement) to some tanks.

Table 3-1 lists some of the components expected to be present in SSTs and selected DSTs. Information presented in Table 3-1 is based largely on historic process flowsheets and known inorganic chemistry (Kupfer 1981) and partly on sparse analytical data for actual tank sludges.

It should be noted that all the sludge types listed in Table 3-1 will contain varying amounts of sodium compounds even after extensive water washing. Some of these sodium compounds are only slightly soluble in water (e.g., $\mathrm{Na}_{2} \mathrm{U}_{2} \mathrm{O}_{7}$, sodium aluminosilicates) while others represent soluble sodium salts incorporated in insoluble metal precipitates.

According to historical records, $\mathrm{BiPO}_{4}$ process waste were stored in SSTS mainly in the B Tank Farm; REDOX process waste were stored in the SX, $S$, and $U$ Tank Farms; pre-1972 PUREX process waste were stored in SSTs in the A, AX, AY, and $A Z$ Tank Farms; while nickel ferrocyanide and $\mathrm{Sr}_{3}\left(\mathrm{PO}_{4}\right)_{2}$ precipitates were stored in SSTs mainly in BY and C Tank Farms. Many of the SSTs currently contain a mixture of process sludges as the result of multiple waste transfers into and out of the SSTs during $40 \mathrm{yr}$ of operations. Various waste management processing (e.g., retrieval, acid dissolution, and tributyl phosphate extraction of uranium of the $\mathrm{BiPO}_{4}$ process waste in the 1950 's, and retrieval and acid dissolution of some early PUREX process sludges in the 1960 's and 1970 's) contributed to mixing of sludges in many SSTs. 
Table 3-1. Types and Composition of Hanford Site Tank Sludges.

\begin{tabular}{|c|c|c|}
\hline Type & \multicolumn{2}{|c|}{ Typical components ${ }^{a, b}$} \\
\hline PUREX process & $\begin{array}{l}-\mathrm{Fe}_{2} \mathrm{O}_{3} \cdot \mathrm{xH}_{2} \mathrm{O} \\
-\mathrm{Al}_{2} \mathrm{O}_{3} \cdot \mathrm{XH}_{2} \mathrm{O} \\
-\quad \mathrm{MnO}_{2} \\
-\quad \mathrm{SiO}_{2} \cdot \mathrm{XH}_{2} \mathrm{O} \\
\end{array}$ & $\begin{array}{l}\text { - } \mathrm{Cr}_{2} \mathrm{O}_{3} \cdot \mathrm{xH}_{2} \mathrm{O} \\
\mathrm{NiO} \\
\text { - } \mathrm{Zr} \text { Metal Fines }\end{array}$ \\
\hline REDOX process ${ }^{c}$ & $\begin{array}{l}-\mathrm{Al}_{2} \mathrm{O}_{3} \cdot \mathrm{xH}_{2} \mathrm{O} \\
-\quad \mathrm{Fe}_{2} \mathrm{O}_{3} \cdot \mathrm{XH}_{2} \mathrm{O} \\
-\quad \mathrm{Al}-\mathrm{Si}(\mathrm{d})^{2}\end{array}$ & $\begin{array}{l}-\mathrm{Cr}_{2} \mathrm{O}_{3} \cdot \mathrm{xH}_{2} \mathrm{O} \\
-\mathrm{MnO}_{2} \\
-\mathrm{NiO}^{2}\end{array}$ \\
\hline $\mathrm{BIPO}_{4}$ process $^{c}$ & $\begin{array}{ll}\text { - } & \mathrm{BiPO} \mathrm{P}_{4} \\
- & \mathrm{Fe}_{2} \mathrm{O}_{3} \cdot \times \mathrm{H}_{2} \mathrm{O} \\
\text { - } & \mathrm{Al}-\mathrm{Si} \\
\end{array}$ & $\begin{array}{l}-\mathrm{LaF}_{3} \\
-\mathrm{Cr}_{2} \mathrm{O}_{3} \cdot \times \mathrm{H}_{2} \mathrm{O} \\
-\mathrm{MnO}_{2}\end{array}$ \\
\hline Nickel ferrocyanide ${ }^{c}$ & $\begin{array}{l}\text { - } \mathrm{Ni}_{2} \mathrm{Fe}(\mathrm{CN})_{6} \\
\text { - } \mathrm{Sr}_{3}\left(\mathrm{PO}_{4}\right)_{2}\end{array}$ & $\begin{array}{l}\text { - } \mathrm{Fe}_{2} \mathrm{O}_{3} \times \mathrm{H}_{2} \mathrm{O} \\
-\mathrm{Na}_{2} \mathrm{U}_{2} \mathrm{O}_{7}\end{array}$ \\
\hline Zircaloy cladding waste & $\begin{array}{ll}-\mathrm{ZrO}_{2} & \times \mathrm{HH}_{2} \mathrm{O} \\
\text { - } & \text { Metal } \\
& \text { Fiuorides }\end{array}$ & $\begin{array}{ll}- & \mathrm{Fe}_{2} \mathrm{O}_{3} \cdot \mathrm{XH}_{2} \mathrm{O} \\
- & \mathrm{Cr}_{2} \mathrm{O}_{3} \times \mathrm{HH}_{2} \mathrm{O} \\
- & \mathrm{NiO}\end{array}$ \\
\hline PFP--T Plant f $^{e}$ & $\begin{array}{l}-\mathrm{Fe}_{2} \mathrm{O}_{3} \cdot \mathrm{xH}_{2} \mathrm{O} \\
-\mathrm{Cr}_{2} \mathrm{O}_{3} \cdot \mathrm{HH}_{2} \mathrm{O} \\
-\mathrm{Ca}(\mathrm{OH})_{2} \\
-\mathrm{Mg}(\mathrm{OH})_{2}\end{array}$ & $\begin{array}{l}-\mathrm{NiO} \\
-\mathrm{CaF}_{2} \\
\mathrm{Al}_{2} \mathrm{O}_{3} \cdot \mathrm{xH}_{2} \mathrm{O}\end{array}$ \\
\hline
\end{tabular}

Data from Kupfer (1981).

Actual tank species may be different from that listed.

cIn single-shell tanks.

Intermetallic compound used as bonding material in

Al-jacketed, $U$ metal slugs.

In double-shell tanks.

${ }^{f}$ Mixed waste from Plutonium Finishing Plant (PFP) and T Plant in Tank 241-SY-102.

PUREX = plutonium-uranium extraction

REDOX = reduction-oxidation

Large amounts of siliceous materials have been deliberately added to certain SSTs (Table 3-2). In other SSTs, various radioactive solids have been added. Retrieval and sorting of waste from these SSTs presents a special challenge. Treatment of sludges in SSTs that contain added foreign material is outside the scope of this report. 
Table 3-2. Miscellaneous Waste in Selected Single-Shell Tanks. ${ }^{a}$

\begin{tabular}{|l|l|}
\hline \multicolumn{1}{|c|}{ Waste type } & \multicolumn{1}{c|}{ Location } \\
\hline Diatomaceous earth $^{\mathrm{b}}$ & $\begin{array}{l}\text { Tanks 241-BX-102, SX-113, TX-116, } \\
\text { TX-117, TY-106, and U-104 }\end{array}$ \\
\hline Portland cement & Tank 241-BX-105 \\
\hline Ion exchange resin & Tank 241-BX-101 \\
\hline Bottles (glass and plastic) & Tanks 241-SX-107 and SX-110 \\
\hline Solid waste & Tank 241-U-101 \\
\hline
\end{tabular}

Data from Functional Requirements Baseline for the Closure of Single-Shell Tanks (Boomer 1990).

24.5 to $86 \mathrm{t}$ ( 27 to 95 tons).

$c_{50 t_{3}}$ (55 tons).

d $7 \mathrm{~m}^{3}$.

${ }^{e} 16$ to 41 bottles containing uranium, plutonium, and fission products.

${ }^{f}$ Inciudes ${ }^{60} \mathrm{Co}$ slugs $\left(70 \mathrm{Ci}{ }^{60} \mathrm{Co}\right)$, experimental fuel elements, shroud tubes, and samarium "poison" ceramic balls. 
WHC-EP-0451

This page intentionally left blank. 


\subsection{SLUDGE SOLUBILIZATION APPROACHES}

Two clearly different approaches (Figure 1-1) to solubilize actinide elements and other important radionuclides (e.g., ${ }^{90} \mathrm{Sr},{ }^{99} \mathrm{Tc}$, and ${ }^{137} \mathrm{Cs}$ ) in Hanford Site sludges are as follows:

1. Fusion

2. Aqueous leaching/dissolution.

Approach 1 entails high-temperature $\left(350{ }^{\circ} \mathrm{C}\right.$ to $\left.800{ }^{\circ} \mathrm{C}\right)$ reactions (fusions) of a11 the water-washed and dried sludge with one or more fluxes (e.g., $\mathrm{KOH}, \mathrm{Na}_{2} \mathrm{CO}_{3}, \mathrm{~B}_{2} \mathrm{O}_{3}$ ). This approach converts silicates, metal oxides, etc., to aqueous-soluble species. The fused reaction products, after cooling to ambient temperature, would be treated with aqueous $\mathrm{HNO}_{3}$ to produce a feed solution suitable for subsequent transuranium extraction (TRUEX) and other process operations. Although not indicated in Figure 1-1, it is assumed that one or more fusions will completely convert all sludge components to aqueoussoluble species. Any undissolved residue remaining after the first (or succeeding) fusions will need to be characterized to determine if it can be disposed of as a LLW or economically vitrified for deep geologic disposal.

The more conventional Approach 2 involves stirred contact of the moist water-washed sludge with a series of aqueous solutions to adequately solubilize actinides and fission products without necessarily dissolving all solid materials. Leaching operations would likely be performed at or near boiling temperatures. The desired goal of this approach is to dissolve all or nearly all the sludge and obtain leached residues that can either be disposed of as LLW or economically vitrified for disposal in a deep geologic

repository. Provision is made in Approach 2 for fusion treatment of residues that do not meet LLW disposal criteria or that cannot be economically vitrified.

A sequential leaching/dissolution approach may not be required for some waste because a single reagent may provide effective sludge dissolution. A single dissolution step is desirable as it will increase waste treatment processing rates. The processing approach chosen (i.e., sequential leaching or single reagent) will be based on weighing the economic advantages of minimizing the mass of waste feed to glass versus the disadvantage of a lengthened time cycle for sludge dissolution.

Each approach has advantages and disadvantages. For example, the fusion approach is a direct, aggressive method to accomplish total dissolution of all sludge. Because the fusion approach involves high temperature reactions, selection of construction materials for equipment, equipment corrosion, and equipment replacement are important concerns. If complete solubilization of sludges is desired, multiple fusions with different fluxes may be required. Lengthy and difficult time cycles will be involved in performing such fusions and associated melt dissolution steps. Finally, the fusion approach will likely generate a large volume of high salt waste that may be only marginally stable to precipitation of silicic acid and other materials. 
WHC-EP-0451

Figure 1-1. Sludge Dissolution Approaches.

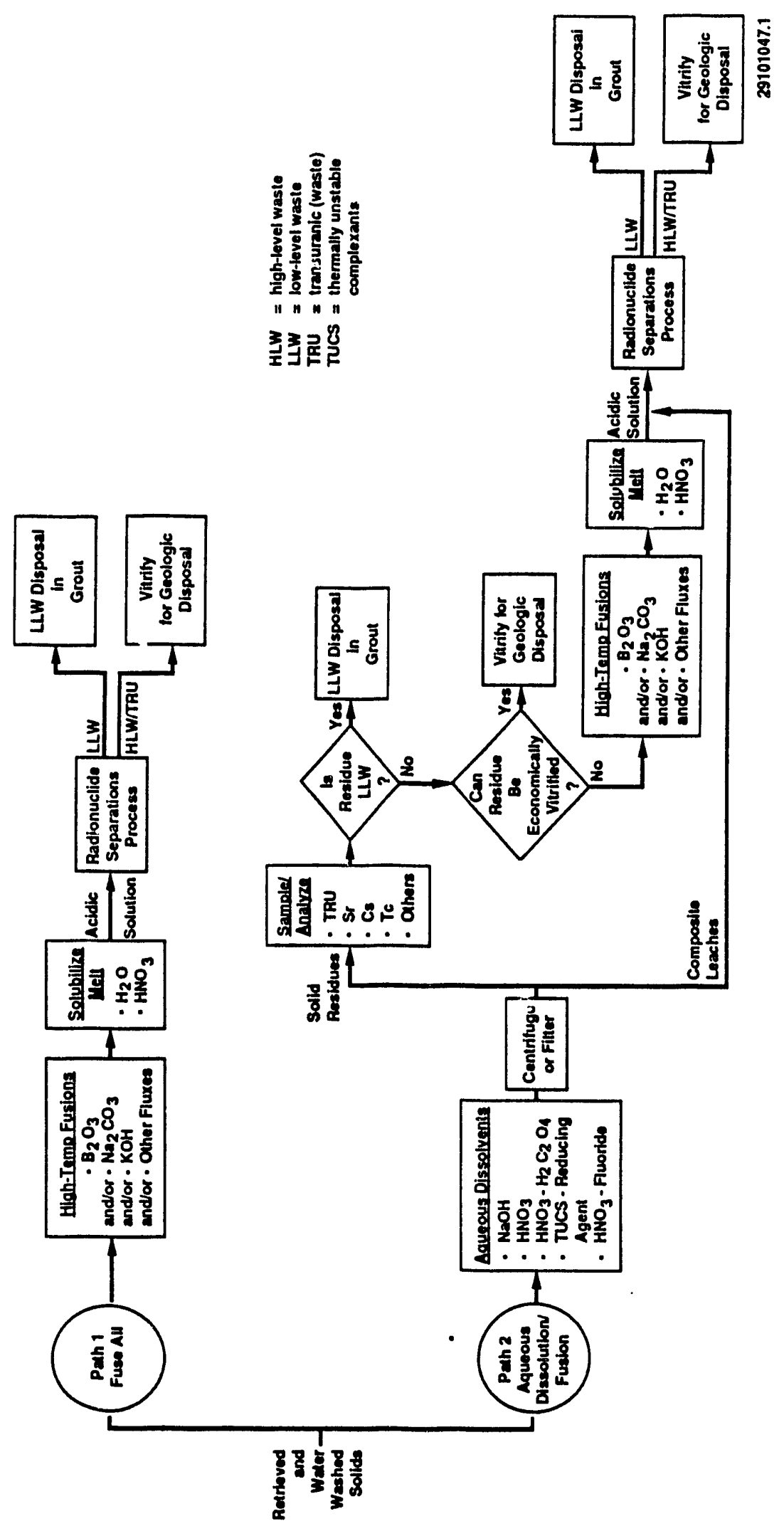


Multi-step sequential leaching/dissolution is a less direct approach than fusion, but because it is carried out at lower temperatures it is also less harsh. Selection of dissolver equipment that can suitably resist attack by $\mathrm{HNO}_{3}$ and $\mathrm{HNO}_{3}-\mathrm{HF}$ solutions is also an important concern. A different sequence of aqueous solutions will likely be needed for each sludge type. Because of the presence of fluoride ion, final blended acidic leachates should be satisfactorily stable to precipitation of silicic acid. This issue needs to be resolved by experimental studies. The need to collect, sample, and analyze leached residues to determine if they can be disposed of as LLW or need to be treated further (i.e., fused) is the primary disadvantage of the aqueous leaching approach. In some cases, the amount of residue remaining after aqueous leaching may be small enough to warrant vitrification without further treatment.

Available sludge dissolution data (Appendix A) are insufficient to permit making a choice between the aqueous leaching and fusion approaches. Therefore, bench-scale tests of both processes should be performed with various tank waste to obtain the information required to select the dissolution processes for pilot plant-scale tests and/or plant-scale implementation. 
WHC-EP-0451

This page intentionally left blank. 
WHC-EP-0451

\subsection{AQUEOUS LEACHING REAGENTS/PROCEDURES}

\subsection{CANDIDATE SLUDGE LEACHANTS}

\subsubsection{Sodium Hydroxide}

In certain instances exposure of water-washed sludges to hot sodium hydroxide ( $\mathrm{NaOH}$ ) solutions may be a beneficial and effective first step in an aqueous leaching process. For example, hot $\mathrm{NaOH}$ solutions may solubilize the aluminum component of the REDOX process sludges provided that mineralization has not occurred. Similarly, $\mathrm{Ni}_{2} \mathrm{Fe}(\mathrm{CN})_{6}$ sludge may be converted to $\mathrm{Fe}(\mathrm{OH})_{3}$, $\mathrm{Ni}(\mathrm{OH})_{2}$, and $\mathrm{NaCN}$ when exposed to $\mathrm{NaOH}$ solutions. There is also a possibility that initial conditioning treatment of all sludges with hot $\mathrm{NaOH}$ solution may make them more amenable to subsequent acidic leachants. The advantages of an initial treatment with $\mathrm{NaOH}$ need to be weighed against the disadvantage of a lengthened dissolution cycle.

\subsubsection{Nitric Acid}

Nitric acid $\left(\mathrm{HNO}_{3}\right)$ solutions are expected to have limited usefulness in dissolving either SST or most DST sludges. This expectation follows from the well-known chemistry of silicates and transition metal oxides that are present in much of the sludge. Nearly complete dissolution of zircaloy cladding sludges is possible by addition of $\mathrm{HNO}_{3}$, however, because these siudges contain significant quantities of fluoride.

\subsubsection{Nitric Acid-0xalic Acid}

Oxalate ion is known to form relatively strong complexes with iron(III) in acidic solutions. Oxalate in aqueous solutions can be readily converted to $\mathrm{C}_{2}$ and $\mathrm{H}_{2} \mathrm{O}$ by digestion in boiling concentrated $\mathrm{HNO}_{3}$ solution or by reaction with $\mathrm{H}_{2} \mathrm{O}_{2}$ in dilute $\mathrm{HNO}_{3}$ solutions. Because of this favorable chemistry, $\mathrm{HNO}_{3}-\mathrm{H}_{2} \mathrm{C}_{2} \mathrm{O}_{4}$ solutions have been extensiveiy considered at the DOE Savannah River Site for potential use in aiding removal of residual sludges that are expected to remain after water sluicing of Savannah River tanks (Hill 1977). The effectiveness of $\mathrm{HNO}_{3}-\mathrm{H}_{2} \mathrm{C}_{2} \mathrm{O}_{4}$ solutions in dissolving a fraction of the various types of Hanford Site tank sludges is not known. Because of the Savannah River Site experience, conceptual flowsheets for pretreatment of Hanford Site SST sludges specify $\mathrm{HNO}_{3}-\mathrm{H}_{2} \mathrm{C}_{2} \mathrm{O}_{4}$ solutions as the primary dissolvent. It is clear that the comprehensive experimental program to investigate aqueous dissolution of Hanford Site tank sludges must include tests of $\mathrm{HNO}_{3}-\mathrm{H}_{2} \mathrm{C}_{2} \mathrm{O}_{4}$ dissolvents.

\subsubsection{Thermally Unstable Complexants-Reducing Agent}

The TUCS compounds are substituted diphosphonic acids. These compounds have been extensively synthesized and characterized at the Argonne National Laboratory. Typical TUCS compounds are 1-hydroxyethane-1, 1-diphosphonic acid 
(HEDPA), and vinylidene-1, 1-diphosphonic acid (VDPA). The HEDPA compound is made and sold commercially under the name Ionquest 201 by Albright \& Wilson, Americas, Ashland, Virginia.

The TUCS-type reagents have the following three important properties.

1. Soluble in aqueous solutions.

2. Form strnng complexes with $+4,+3$, and some +2 metal ions in highly acidic $\left(>0.5 \mathrm{M} \mathrm{HNO}_{3}\right)$ solutions.

3. Easily and completely decompose to water, $\mathrm{CO}_{2}$, and $\mathrm{H}_{3} \mathrm{PO}_{4}$ by digestion at elevated temperatures in $\mathrm{HNO}_{3}$ or $\mathrm{HNO}_{3}-\mathrm{H}_{2} \mathrm{O}_{2}$ solutions. Potential listing of TUCS compounds by the U.S. Environmental Protection Agency is not of concern.

The TUCS-type reagents were originally developed for their potential application in nuclear solvent extraction process operations. For example, TUCS reagents are expected to be eventually used as agents for masking, stripping, and solvent cleanup.

Chiarizia and Horwitz (1990) have recently discovered that certain combinations of TUCS compounds and reducing agents (e.g., ascorbic acid, sodium dithionite, and sodium formaldehydesulfoxylate) effectively accelerate the dissolution of alpha- $\mathrm{FeOOH}$, the mineral goethite. In particular, solutions of Ionquest 201 and sodium formaldehydesulfoxylate rapidly dissolve $\mathrm{FeOOH}$. These results suggest that TUCS compounds may find great application in solubilizing hydrated metal oxide components of Hanford Site tank sludges.

In $\mathrm{HNO}_{3}$ solutions, TUCS reagents complex iron(III) and other transition inetals more strongly than does oxalate ion. Also aqueous solutions containing a TUCS compound and a reducing agent efrectively dissolve goethite, $\mathrm{FeOOH}$, a refractory compound which could be in some Hanford Site tanks. Such solutions may also solubilize other metal oxides in Hanford Site tank sludges. Thus, there is justification for including, on a high-priority basis, aqueous TUCSreducing agents as candidate dissolvents in a sludge dissolution test plan. Experiments involving TUCS reagents also need to be performed to determine if they can be employed in combination with a reducing agent directly in $\mathrm{HNO}_{3}$ solution, or if satisfactory sludge dissolution can be realized only in the absence of $\mathrm{HNO}_{3}$.

\subsubsection{Nitric Acid-Fluoride}

In dissolving sludges in Hanford Site SSTs and DSTs, $\mathrm{HNO}_{3}$ solutions containing $\mathrm{F}^{-}$may be used in the following two ways:

- Initial dissolvent

- Final dissolvent after previous treatment with other aqueous reagents. 
The latter application is thoroughly discussed in the remaining text of this section. It is important to recognize, however, the need to completely investigate the extent that $\mathrm{HNO}_{3}-\mathrm{F}^{\circ}$ solutions will directly dissolve waterleached sludges. There is a good possibility that $\mathrm{HNO}_{3}-\mathrm{F}^{-}$solutions alone will sufficiently solubilize all sludge types. Great advantages in reduced time cycles, reduced dissolver corrosion, and reduced costs can be realized.

\subsubsection{Concentrated Sulfuric Acid or Phosphoric Acid}

Of many reagents tested (Appendix $B$ ), only hot $\left(110{ }^{\circ} \mathrm{C}\right.$ ) $18 \mathrm{M} \mathrm{H}_{2} \mathrm{SO}_{4}$ and $14.6 \mathrm{M} \mathrm{H}_{3} \mathrm{PO}_{4}$ solutions were found (Hepworth 1957) to completely dissolve freshiy precipitated and dried $\mathrm{Cs}_{2} \mathrm{ZnFe}(\mathrm{CN})_{6}$. The phosphoric acid $\left(\mathrm{H}_{3} \mathrm{PO}_{4}\right)$ dissolvent produced a clear solution while the sulfuric acid $\left(\mathrm{H}_{2} \mathrm{SO}_{4}\right)$ solution yielded a yellow solution plus an unidentified precipitate. The $\mathrm{H}_{2} \mathrm{SO}_{4}$ is more effective than $\mathrm{H}_{3} \mathrm{PO}_{4}$ for dissolving $\mathrm{Cs}_{2} \mathrm{ZnFe}(\mathrm{CN})_{6}$.

The results (Hepworth 195i) suggest that either or both concentrated $\mathrm{H}_{2} \mathrm{SO}_{4}$ or $\mathrm{H}_{3} \mathrm{PO}_{4}$ solutions will dissolve the ferrocyanide solids in Hanford Site SSTs. Experimental work to verify this hypothes is is needed. If either or both reagents will satisfactorily dissolve actual ferrocyanide sludges then follow-on engineering studies and bench-scale tests will be needed to address several important issues. These issues include: (1) corrosivity and suitable construction materials for dissolvers and other process equipment;

(2) processes for removal of ${ }^{137} \mathrm{Cs}$ from the dissolved ferrocyanide solids if necessary; (3) removal of other nuclides (e.g., transuranium elements, ${ }^{90} \mathrm{Sr}$,

${ }^{99} \mathrm{Tc}$ ) from the dissolution of ferrocyanide solids and processes; and

(4) eventual disposition of the cyanide in the ferrocyanide solids.

\subsubsection{0thers}

Other highly aggressive leachants include 5 to $12 \mathrm{M} \mathrm{HCl}$ and aqua regia $\left(\mathrm{HNO}_{3}-\mathrm{HCl}\right)$ in a pressurized vessel. Hydrochloric acid is the classic reagent used to attack iron ores (e.g., hematite, limonite) for subsequent wet chemical analyses. Hot aqua regia solution is effective in dissolving $\mathrm{FeOOH}$ and other metal oxides present in Hanford Site tank sludges (Appendix A). These reagents are well suited to laboratory-scale characterization of waste sludges; however, plant-scale uses of heated aqua regia solutions for waste treatment would present many challenges including the need for suitable corrosion-resistant construction materials and the need to convert from a chloride-nitrate system to a nitrate system for subsequent radionuclide removal procedures. Provided they are sufficiently effective, substitution of $\mathrm{HNO}_{3}$-oxalic and/or TUCS-reducing agent leachants for $\mathrm{HCl}$ or aqua regia is the preferred option. 
Hot $\mathrm{HNO}_{3}-\mathrm{HF}-\mathrm{HCl}$ solution, under pressure, was quite effective in dissolving most of the residue left after Hanford Site tank sludge was treated with $5 \mathrm{M} \mathrm{HCl}$. Several factors (e.g., construction materials, pressurization of radioactive solutions) oppose plant-scale use of such a solution.

Pacific Northwest Laboratory personnel have concluded that aqueous solution containing EDTA may also be useful in solubilizing ferrocyanide solids.

\subsection{RECOMMENDED REAGENTS AND PROCEDURES}

As noted in Section 4.0 , the desired goal of the aqueous leaching approach is to dissolve all or nearly all of the sludge to reduce the waste volume requiring vitrification and geologic repository disposal. Use of a single dissolution reagent rather than sequential leachants is desirable to increase processing rates; however, sequential leaching may be necessary for some waste. It is recommended that the effectiveness of $\mathrm{HNO}_{3}$-oxalic and TUCSreducing agent solutions be investigated for a one-step dissolution approach for all the different types of tank sludges. The use of $\mathrm{HNO}_{3}-\mathrm{HF}$ should be investigated for all waste types except zircaloy cladding waste (since $\mathrm{HNO}_{3}$ alone has been shown to be successful). Evaluation of the results from comparative leaching tests with these metal oxide dissolvents should lead to a choice of one reagent over the other for leaching each type of sludge.

Recommended sequential leaching reagents and their order of application to Hanford Site sludge types are listed in Table 5-1. These recommendations derive from consideration of both the projected components (Table 3-1) of various sludge types and the known or expected dissolution capacity of leachants.

Residues remaining after leaching with $\mathrm{NaOH}, \mathrm{HNO}_{3}-\mathrm{H}_{2} \mathrm{C}_{2} \mathrm{O}_{4}$, and/or TUCSreducing agent solutions should be analyzed to determine their TRU and radioactive fission product content. Subsequently, the action of heated $\mathrm{HNO}_{3}-\mathrm{HF}$ solutions in leaching radioactive components from the residual solids should be determined for each sludge type.

Portions of solids before and after leaching with $\mathrm{HNO}_{3}-\mathrm{F}^{-}$solutions should be fused with $\mathrm{KOH}$ or $\mathrm{NaOH}$ (see Section 6.0) to solubilize them. Results of such fusion tests will help determine: (1) if high temperature fusions are necessary to adequately solubilize radioactive constituents and (2) if fusion with $\mathrm{NaOH}$ or $\mathrm{KOH}$ is more effective than leaching with $\mathrm{HNO}_{3}-\mathrm{F}^{-}$solutions for solubilizing significant radioactive components. 
Table 5-1. Proposed Sequential Leaching Schemes For Hanford Site Tank Sludges--Preliminary Recommendations.

\begin{tabular}{|c|c|}
\hline Sludge type & Sequential leaching scheme $^{a}$ \\
\hline PUREX process & $\begin{array}{ll}\text { 1. } & \mathrm{HNO}_{3} \\
\text { 2. } & \mathrm{TUCS} \text {-reducing agent } \\
\mathrm{HNO}, \mathrm{c} & \text { and } / \mathrm{Or} \\
\mathrm{HN} & -\mathrm{H}_{2} \mathrm{C}_{2} \mathrm{O}_{4} \\
\text { 3. } & \mathrm{HNO}_{3}-\mathrm{F}\end{array}$ \\
\hline REDOX process $^{d}$ & Same as for PUREX process sludge \\
\hline $\mathrm{BiPO}_{4}$ process & Same as for PUREX process sludge \\
\hline Nickel ferrocyanide & $\begin{array}{l}\text { Scheme } 1 \text { : } \\
\text { Concentrated } \mathrm{H}_{3} \mathrm{PO}_{4} \text { or } \mathrm{H}_{2} \mathrm{SO}_{4} \\
\text { Scheme 2: } \\
\text { 1. } \quad \mathrm{NaOH} \\
\text { 2. } \quad \mathrm{HNO}_{3} \\
\text { 3. } \quad \mathrm{TUCS}_{-}-\mathrm{reducing}_{3} \mathrm{C}_{2} \mathrm{O}_{4}\end{array}$ \\
\hline Zircaloy cladding waste & $\begin{array}{l}\text { 1. } \mathrm{HNO}_{3} \\
\text { 2. } \mathrm{TUCS}^{-} \text {reducing agent and/or } \\
\mathrm{HNO}_{3}-\mathrm{H}_{2} \mathrm{C}_{2} \mathrm{O}_{4}\end{array}$ \\
\hline PFP--T-Plant & Same as for PUREX process sludge \\
\hline
\end{tabular}

${ }^{a}$ Aqueous solutions to be employed in the listed order.

${ }^{b}$ Candidate reducing agents include ascorbic acid (first choice), sodium dithionite, and sodium formaldehyde-sulfoxylate.

'The action of thermally unstable complexants (TUCS)-reducing agent$\mathrm{HNO}_{3}$ solutions should also be tested.

The action of $\mathrm{NaOH}$ solutions in solubilizing the aluminum portion of reduction-oxidation (REDOX) process sludges should al so be tested.

Adequate safety procedures should be observed in handling ferrocyanide solids. To prevent explosive reactions between solid ferrocyanide compounds and nitrate or nitrate compounds, ferrocyanide solids should be washed with water to remove nitrate and nitrate compounds before exposure to other leachants.

PUREX = plutonium-uranium extraction.

PFP = Plutonium Finishing Plant. 
WHC-EP-0451

This page intentionally left blank.

5-6 


\subsection{FUSION REAGENTS AND PROCEDURES}

Common fluxes for attacking silicates and mineral oxides are typically alkali metal compounds. Basic fluxes employed for attacking silicates include alkali carbonates, hydroxides, and peroxides (Table 6-1). Potassium pyrosulfate and $\mathrm{B}_{2} \mathrm{O}_{3}$ are two important acidic fluxes for decomposing certain metal oxides as welt as silicates. Sodium peroxide is a powerful oxidizing flux for sulfides, platinum alloys, and minerals of $\mathrm{Cr}, \mathrm{Sn}$, and $\mathrm{Zr}$.

Molten $\mathrm{KOH}$ or $\mathrm{NaOH}$ are strong candidates for decomposing any residue left after previous sequential leaching of sludges with a variety of aqueous reagents (see Table 5-1). Such residues are likely to be refractory silicates not readily attacked by $\mathrm{HNO}_{3}$-fluoride solutions. Molten $\mathrm{KOH}$ and $\mathrm{NaOH}$ can be satisfactorily contained in nickel containers.

Because it decomposes both metal oxides and silicates, $\mathrm{B}_{2} \mathrm{O}_{3}$ is the leading flux candidate for fusing water-washed sludge that has not been further leached (Approach 2, Figure 1-1). Other flux candidates for this task include $\mathrm{Na}_{2} \mathrm{CO}_{3}$ and, less attractively, potassium pyrosulfate. Laboratoryscale fusions with $\mathrm{B}_{2} \mathrm{O}_{3}$ are typically performed in platinum crucibles; suitable construction materials for performing plant-scale fusions with $\mathrm{B}_{2} \mathrm{O}_{3}$ will need to be determined.

Table 6-1. Potential Fluxes For Solubilizing Hanford Site Tank Sludges.

\begin{tabular}{|l|c|l|}
\hline \multicolumn{1}{|c|}{ Flux } & Melting point $\left({ }^{\circ} \mathrm{C}\right)$ & Type of substance attacked \\
\hline $\mathrm{K}_{2} \mathrm{~S}_{2} \mathrm{O}_{7}$ & 300 & $\begin{array}{l}\text { Acidic flux for slightly } \\
\text { soluble oxides }\end{array}$ \\
\hline $\mathrm{NaOH}$ or $\mathrm{KOH}$ & 318 & Silicates \\
\hline $\mathrm{B}_{2} \mathrm{O}_{3}$ & 577 & $\begin{array}{l}\text { Acid flux for decomposition } \\
\text { of silicates and oxides }\end{array}$ \\
\hline $\mathrm{Na}_{2} \mathrm{CO}_{3}$ & 851 & $\begin{array}{l}\text { Silicates and silica- } \\
\text { containing, Al-containing } \\
\text { phosphates, and sulfates }\end{array}$ \\
\hline $\mathrm{Na}_{2} \mathrm{O}_{2}$ & Decomposes & Basic oxidizing flux \\
\hline
\end{tabular}

"Adapted from Fundamentals of Analytical Chemistry, (Skoog and West 1969). 
WHC-EP-0451

This page intentionally left blank.

6-2 


\subsection{REFERENCES}

Boomer, K. D., et al., 1990, Functional Requirements Baseline for the Closure of Single-Shell Tanis, WHC-EP-0338, Westinghouse Hanford Company, Richland, Washingtor.

Chiarizia, R., and E. P. Hürwitz, 1990, New Formulations for Iron Oxides Dissolution, Argonne Nationial Laboratory, Argonne, Illinois.

Hepworth, J. L., E. D. McClanahan, Jr., and R. L. More, 1957, Cesium Packaging Studies: Conversion of Cesium Zinc Ferrocyanide to a Cesium Chloride Product, HW-48832, General Electric Company, Richland, Washington.

Hill, A. J., Jr., and R. F. Bradley, 197i, Chemical Dissolving of Sludge from a High-Level Waste Tank at the Savannah River Plant, DP-1471, E. I. Du Pont de Nemours, Inc., Aiken, South Carolina.

Kupfer, M. J., 1981, Preparation of Nonradioactive Substitutes for Radioactive Waste, DOE/ET 41900-8, Rockwe 11 Hanford Operations, Richland, Washington.

Skoog, D. A., and D. M. West, 1969, Fundamentals of Analytical Chemistry, 2nd Ed., Holt, Rinehart, and Winston, Inc., New York, New York. 
WHC-EP-0451

This page intentionally left blank. 
WHC-EP-0451

\section{APPENDIX A}

\section{REVIEW OF EXISTING SLUDGE DISSOLUTION EXPERIMENTAL DATA}


WHC-EP-0451

This page intentionally left blank. 


\section{APPENDIX A \\ REVIEW OF EXISTING SLUDGE DISSOLUTION EXPERIMENTAL DATA}

\section{A-1.0 SINGLE-SHELL TANK SLUDGE}

Table A-1 summarizes results obtained by Westinghouse Hanford Company scientists in dissolving samples of actual single-shell tank solids for characterization. The samples dissolved contained varying amounts of sludge and saltcake that consists mainly of water-soluble sodium salts. Most of the sludges examined resulted from neutralization of acid waste from the plutonium-uranium extraction (PUREX) and bismuth phosphate $\left(\mathrm{BiPO}_{4}\right.$ ) processes. Based upon historical records, $\mathrm{Ni}_{2} \mathrm{Fe}(\mathrm{CN})_{6}$ solids were likely present in two of the TY tank samples while reduction-oxidation (REDOX) process sludge may have been present in the samples from the BX tanks.

In each case a standard dissolution procedure was employed (detailed in Table A-1, footnotes $b, c$, and d). The first two reagents were used at $\sim 35{ }^{\circ} \mathrm{C}$ while the aqua regia-HF solution was used at $110{ }^{\circ} \mathrm{C}$ in a pressurized vessel. This procedure was devised more by the need to ensure complete dissolution of various sludge types for characterization than by development of a plan for plant-scale sludge dissolution. For this reason the standard dissolution procedure for single-shell tank waste characterization may not be representative of the leaching conditions that would be used in a full-scale process for solubilizing the sludges for removal of radionuclides or hazardous chemicals.

Simple water leaching dissolved most of the samples of solids from Tanks 102-TY and 103-A; these samples, as indicated in Table A-1, contained mainly saltcake. In many instances the combination of water and dilute $\mathrm{HCl}$ leaches dissolved substantial amounts of solids. But in other cases, the water and 5 M HCl leaches dissolved only minor amounts of solids. These differences in response to the water-HCl leaches may be attributable to differences in the degree of dehydration of $\mathrm{Fe}_{2} \mathrm{O}_{3} \cdot \mathrm{XH}_{2} \mathrm{O}$ (a principal sludge component) to refractory material.

Except for sludge solids from Tanks 101-TY, 104-8X, and 105-BX, the standard leach procedure successfully dissolved 99 to $100 \%$ of the siudge and saltcake. In particular, the final $\mathrm{HNO}_{3}-\mathrm{HCl}-\mathrm{HF}$ leach at $110^{\circ} \mathrm{C}$ was effective in solubilizing solids remaining after water and dilute $\mathrm{HCl}$ leaching. The data, of course, are insufficient to determine which factor or factors (i.e., higher temperature, presence of $\mathrm{HF}$, presence of $\mathrm{HNO}_{3}$, or higher $\mathrm{HCl}$ concentration) are responsible for the effective dissolution results. It can be supposed that the undissolved final residue in the BX Tank samples contained relatively large amounts of aluminum as the result of the presence of REDOX process sludge. 
Table A-1. Summary of Dissolution Tests with Various Single-Shell Tank Waste Samples.

\begin{tabular}{|c|c|c|c|c|}
\hline Sludge Type & Tank & $\begin{array}{c}\text { Cumulative } \\
\mathrm{H}_{2} \mathrm{O}^{b}\end{array}$ & $\begin{array}{c}\% \text { Dissolve } \\
\mathrm{HCl}^{\mathrm{c}}\end{array}$ & $\begin{array}{l}\text { After Leaching } \\
\mathrm{HNO}_{3}-\mathrm{HCl}-\mathrm{HF}^{\mathrm{d}}\end{array}$ \\
\hline 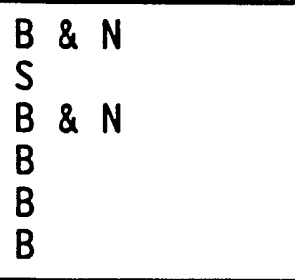 & $\begin{array}{r}241-T Y-101 \\
-T Y-102 \\
-T Y-103 \\
-T Y-104 \\
-T Y-105 \\
-T Y-106\end{array}$ & $\begin{array}{l}13.3 \\
89.4 \\
40.0^{\mathrm{g}} \\
40.6^{\mathrm{h}} \\
27.1^{\mathrm{g}} \\
23.5^{\mathrm{g}}\end{array}$ & $\begin{array}{c}76.5 \\
100.0^{9} \\
92.7^{9} \\
88.0^{h} \\
100.0^{g} \\
22.8^{g}\end{array}$ & $\begin{aligned} & 94.8^{e} \\
&(f) \\
&>99.9 \\
&>99 . h \\
&(f)^{\prime} \\
&>99.9\end{aligned}$ \\
\hline $\begin{array}{l}P \\
S \\
P\end{array}$ & $\begin{array}{r}241-A-102 \\
-A-103 \\
-A-106\end{array}$ & $\begin{array}{l}64.8^{9} \\
95.3^{9} \\
75.3^{3}\end{array}$ & $\begin{array}{l}79.4^{9} \\
95.8^{9} \\
68.3^{9}\end{array}$ & $\begin{array}{l}>99.9 \\
>99.9 \\
100 .\end{array}$ \\
\hline $\begin{array}{lll}B & \& & P \\
B & \& & P \\
P & & \\
P & \end{array}$ & $\begin{array}{r}241-C-103 \\
-C-104 \\
-C-105 \\
-C-106\end{array}$ & $\begin{array}{r}25.5^{9} \\
31.1 \\
2.0 \\
34.5\end{array}$ & $\begin{array}{c}14.7^{9} \\
42.2 \\
4.7 \\
19.7\end{array}$ & $\begin{array}{l}99.0^{9} \\
100 . \\
100 . \\
98.9\end{array}$ \\
\hline $\begin{array}{l}\mathrm{B}_{\mathrm{B}^{i}} \& \mathrm{R} \\
\end{array}$ & $\begin{array}{r}241-B X-104 \\
-B X-105\end{array}$ & $\begin{array}{r}6.9^{9} \\
27.8^{9}\end{array}$ & $\begin{array}{l}18.5^{9} \\
41.0^{9}\end{array}$ & $\begin{array}{l}87.2^{9} \\
94.2^{9}\end{array}$ \\
\hline
\end{tabular}

${ }^{\mathrm{a}} \mathrm{B}=\mathrm{BiPO}_{4}, \mathrm{~N}=\mathrm{Ni}_{2} \mathrm{Fe}(\mathrm{CN})_{6}, \mathrm{P}=$ plutonium-uranium extraction (PUREX) process, $R=$ reduction-oxidation (REDOX) process, $S=$ salt cake. (See Table 2 and associated text.)

${ }^{b}$ Nominally three contacts ( $5 \mathrm{~g}$ waste/15 $\mathrm{ml} \mathrm{H}_{2} \mathrm{O}$ ) at $\sim 35{ }^{\circ} \mathrm{C}$.

${ }^{c}$ Nominally three contacts of residue from water leaching with $15 \mathrm{ml}$ portions of $5 \mathrm{M} \mathrm{HCl}$ at $\sim 35{ }^{\circ} \mathrm{C}$.

${ }^{d}$ Residue, if any, from preceding $\mathrm{HCl}$ leach contacted with aqua regia containing a couple drops of concentrated HF in a Teflon* pressure vessel for $4 \mathrm{~h}$ at $\sim 110{ }^{\circ} \mathrm{C}$.

Eelatinous residue remained.

Not performed.

${ }_{9}^{\text {A }}$ verage of data points with two separate waste samples.

hAverage of data points with four separate waste samples.

'Some REDOX process sludge may also be present.

*Tefion is a trademark of E. I. DuPont de Nemours, Inc. 
As noted, portions of the sludge solids in Tank 101-TY, 104-BX, and 105-BX were not completely dissolved using the standard leach procedure. If complete solubilization of the waste is desired, the waste in these tanks (and possibly other waste in the remaining single-shell taliks) may prove difficult to dissolve in a full-scale treatment facility without using aggressive leaching conditions and reagents.

\section{A-2.0 DISSOLUTION OF ACTUAL DOUBLE-SHELL TANK SOLIDS}

\section{A-2.1 NEUTRALIZED CLADDING REMOVAL WASTE SOLIDS}

Neutralized Zirflex process waste is stored in double-shell tanks 103-AW and 105-AW. Scientists at Pacific Northwest Laboratory performed dissolution studies with 2- to 3-g samples of solids from both tanks. (These experiments were conducted with composites of core samples taken from both 103-AW and 105-AW tanks.) Treatment of as-received unwashed neutralized cladding removal waste solids with 0.5 to $1 \mathrm{M} \mathrm{HNO}_{3}$ at $\sim 25{ }^{\circ} \mathrm{C}$ dissolved 92 to $98 \%$ of the $\mathrm{Zr}, 82$ to $96 \%$ of the $\mathrm{Pu}$, and 93 to $99 \%$ of the Am. A small amount of the sludge was not dissolved; the solid residue contained more than $100 \mathrm{nCi} / \mathrm{g}$ of transuranic (waste) elements. The residue was soluble in $5 \mathrm{M} \mathrm{HNO}-0.5 \mathrm{M} H F$ solution at $100{ }^{\circ} \mathrm{C}$ but $\mathrm{Zr}$ precipitated when the solution was cooled. Water-washed neutralized cladding removal waste sludge is not appreciably soluble in $\mathrm{HNO}_{3}$; water washing removes $\mathrm{NaF}$ which promotes dissolution of $\mathrm{ZrO}_{2} \cdot \mathrm{XH}_{2} \mathrm{O}$ in $\mathrm{HNO}_{3}$.

\section{A-2.2 PLUTONIUM FINISHING PLANT AND T PLANT SLUdge}

Pacific Northwest Laboratory personnel recently characterized the chemical composition of the sludge currently stored in double-shell tank 102SY. Solids in this tank originated from neutralization of acidic waste solutions generated in Plutonium Finishing Plant and T Plant operations.

A $0.25-\mathrm{g}$ sample of dried $\left(110^{\circ} \mathrm{C}\right)$ solids from Tank $102-\mathrm{SY}$ was fused with $2.0 \mathrm{~g}$ of $\mathrm{KOH}$ and $0.5 \mathrm{~g} \mathrm{KNO}_{3}$ at $500{ }^{\circ} \mathrm{C}$ for $0.5 \mathrm{~h}$. After cooling to room temperature the resulting solidified fused mass was completely dissolved by agitation with $250 \mathrm{~mL}$ of $1.2 \mathrm{M} \mathrm{HCl}$. These results with actual sludge demonstrate the ability of the fusion approach.

\section{A-2.3 COMPLEXED CONCENTRATE SOLIDS}

Complexed concentrate waste is stored in five Hanford Site double-shell tanks. The complexed concentrate waste is the concentrated raffinate from ${ }^{90} \mathrm{Sr}$ solvent extraction operations performed in the 1970's and 1980's. The liquid portion of complexed concentrate waste contains high concentrations of sodium salts $\left(\mathrm{NaNO}_{3}, \mathrm{NaNO}_{2}, \mathrm{Na}_{2} \mathrm{CO}_{3}\right.$, and $\mathrm{NaOH}$ ) and organic complexants such as glycolate and citrate. Some solids containing both inorganic and organic constituents are also present in complexed concentrate waste. Scientists at PNL performed some dissolution tests with the solids present in a sample of complexed concentrate waste taken from double-shell tank 107-AN. Portions of both as-received and water-washed complexed concentrate solids were treated in

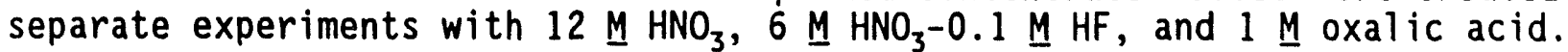


In all cases more than $99 \%$ of the solids dissolved. Rockwell Hanford Operations scientists reported $12 \mathrm{M} \mathrm{HNO}-0.2 \mathrm{M} \mathrm{HF}$ was required to dissolve water insoluble solids from double-shell tank 10l-AY (Kupfer 1981). The solids were found to contain significant amounts of siliceous materials.

Chemical analyses of complexed concentrate waste from double-shell tank 103-SY were performed by Westinghouse Hanford Company personne1. The water insoluble portion of the waste was contacted with 12 M $\mathrm{HNO}_{3}-1 \mathrm{sO} .1 \mathrm{M} \mathrm{HF}$ at room temperature. Some solids (less than $50 \%$ volume) remained undissolved after the acid leach. A quantitative determination of the extent of solids dissolution was not made. 
WHC-EP-0451

APPENDIX B

REAGENTS TESTED FOR DISSOLUTION OF CESIUM ZINC FERROCYANCIDE PRECIPITATES 
WHC-EP-0451

This page intentionally left blank. 
WHC-EP-0451

\section{APPENDIX B}

\section{REAGENTS TESTED FOR DISSOLUTION OF CESIUM ZINC FERROCYANIDE PRECIPITATES}

Table B-1 reproduces Table 5 of Cesium Packaging Studies: Conversion of Cesium Zinc Ferrocyanide to a Cesium Chloride Product* and summarizes the results obtained in attempts to find aqueous reagents that would completely solubilize both freshly precipitated and dried cesium zinc ferrocyanide $\left[\mathrm{Cs}_{2} \mathrm{ZnFe}(\mathrm{CN})_{6}\right]$.

*Hepworth, J. L., E. D. McClanahan, Jr., and R. L. More, 1957, Cesium Packaging Studies: Conversior of Cesium Zinc Ferrocyanide to a Cesium Chloride Product, HW-48832, General Electric Company, Richland, Washington. 
Table B-1. Dissolution of Cesium Zinc Ferrocyanide.

\begin{tabular}{|c|c|c|c|c|}
\hline Reagent & $\begin{array}{c}\text { Concentration } \\
(\underline{M})\end{array}$ & $\begin{array}{c}\text { Temperature } \\
\left({ }^{\circ} \mathrm{C}\right)\end{array}$ & $\begin{array}{l}\text { Change in } \\
\text { physical } \\
\text { appearance }\end{array}$ & $\begin{array}{c}\text { Cesium } \\
\text { recovery } \\
(\%)\end{array}$ \\
\hline Nitric acid & 15 & 25 & $\begin{array}{l}\text { Yellow } \\
\text { precipitate }\end{array}$ & 10 \\
\hline Nitric acid & Fuming & 25 & $\begin{array}{l}\text { Yellow } \\
\text { precipitate }\end{array}$ & 10 \\
\hline $\begin{array}{l}\text { Hydrochloric } \\
\text { acid }\end{array}$ & 12.4 & 25 & $\begin{array}{l}\text { Green } \\
\text { precipitate }\end{array}$ & 15 \\
\hline Acetic acid & 17.5 & 25 & No change & 1 \\
\hline $\begin{array}{l}\text { Acetic- } \\
\text { hydrochloric }\end{array}$ & $8-6$ & 25 & $\begin{array}{l}\text { Green } \\
\text { precipitate }\end{array}$ & 5 \\
\hline $\begin{array}{l}\text { Perchloric } \\
\text { acid }\end{array}$ & 11.7 & 25 & $\begin{array}{l}\text { Brown } \\
\text { precipitate }\end{array}$ & 5 \\
\hline $\begin{array}{l}\text { Sulfuric } \\
\text { acid }\end{array}$ & 18 & 25 & $\begin{array}{l}\text { Yellow- } \\
\text { green } \\
\text { precipitate }\end{array}$ & 30 \\
\hline $\begin{array}{l}\text { Sulfuric } \\
\text { acid }\end{array}$ & 18 & 110 & $\begin{array}{l}\text { Yellow } \\
\text { solution } \\
\text { and } \\
\text { precipitate }\end{array}$ & 100 \\
\hline Aqua regia & -- & 25 & Black & 25 \\
\hline Aqua regia & -- & 110 & $\begin{array}{l}\text { Clear } \\
\text { solution }\end{array}$ & 100 \\
\hline $\begin{array}{l}\text { Phosphoric } \\
\text { acid }\end{array}$ & 14.6 & 25 & $\begin{array}{l}\text { Partly } \\
\text { dissolved }\end{array}$ & 25 \\
\hline $\begin{array}{l}\text { Phosphoric } \\
\text { acid }\end{array}$ & 14.6 & 110 & $\begin{array}{l}\text { Clear } \\
\text { solution }\end{array}$ & 100 \\
\hline $\begin{array}{l}\text { Hydrofiloric } \\
\text { acid }\end{array}$ & 27.6 & 25 & $\begin{array}{l}\text { Green } \\
\text { precipitate }\end{array}$ & 5 \\
\hline $\begin{array}{l}\text { Sodium } \\
\text { hydroxide }\end{array}$ & 10 & 25 & None & 1 \\
\hline $\begin{array}{l}\text { Ammonium } \\
\text { hydroxide }\end{array}$ & 15 & 25 & None & 1 \\
\hline $\begin{array}{l}\text { Sodium } \\
\text { dichromate }\end{array}$ & 2 & 25 & $\begin{array}{l}\text { Orange } \\
\text { precipitate }\end{array}$ & 1 \\
\hline
\end{tabular}


WHC-EP-0451

DISTRIBUTION

Number of Copies

\section{ONSITE}

8

U.S. Department of Energy-Richland Field office

M. J. Anthony
K. W. Bracken
P. K. Clark
R. D. Freeberg
R. E. Gerton
J. M. Hennig
P. E. Lamont

Public Reading Room

Pacific Northwest Laboratory

J. F. Fletcher

L. K. Holton

E. 0 . Jones

D. E. Kurath

J. E. Mende 1

J. L. Swanson

K. D. Wiemers
R4-04

A5-22

A5-21

A5- 19

A5-21

A5-21

A5-10

Al-65

K6-31

$\mathrm{P} 7-43$

K2-12

P7 -43

P7-18

P7-25

P7-14

Westinghouse Hanford Company

J. N. Appel

C. A. Augustine

R2-07

S. A. Barker

$\mathrm{R} 2-28$

W. B. Barton

R2-07

J. D. Berger

S6-70

G. R. Bloom

LO-18

L4-71

A. L. Boldt

H5- 49

K. D. Boomer

W. F. Brehm

H5- 49

M. A. Cahill

N2-O1

R3-46

J. W. Camman

J. S. Garfield

H4-14

R3-63

C. J. Geier

B2-19

E. W. Gerber

L5-62

K. A. Giese

R2-14

R. L. Gilchrist

L5-63

F. Grey

R1-08

V. W. Hall

L4-88

D. W. Hamilton

R2-28

J. J. Holmes

L5-55

J. 0. Honeyman

A4-25

B. K. Horsager

$54-68$

J. R. Jewett

T6-50 
WHC-EP-0451

DISTRIBUTION (continued)

Number of Copies

ONSITE

West inghouse Hanford Company (continued)

N. W. Kirch

M. J. Klem

R2-11

M. J. Kupfer (3)

R2-14

R. E. Lerch

H5-49

S. S. Lowe

B2-35

G. A. Meyer

R2-07

R. M. Orme

R2-28

D. E. Place

R2-07

J. G. Propson

S6-70

J. A. Rawl ins

R2-18

R. E. Raymond

H0-36

C. R. Relchmuth

RI-80

D. A. Reynolds

S4-58

J. H. Roecker

R2-11

L. M. Sasaki

R2-28

P. S. Schaus

R2-12

L. C. Stegen

A4-90

R. A. Watrous

E. T. Weber

R2-07

G6-08

W. I. Winters

G6-08

D. D. Wodrich

T6-50

B3-72

R. D. Wojtasek

L4-92

B. A. Wolfe

L5-55

W. F. Zuroff

Central Files

R2-14

Document Clearance

L8-04

Administration (3)

R1-08 

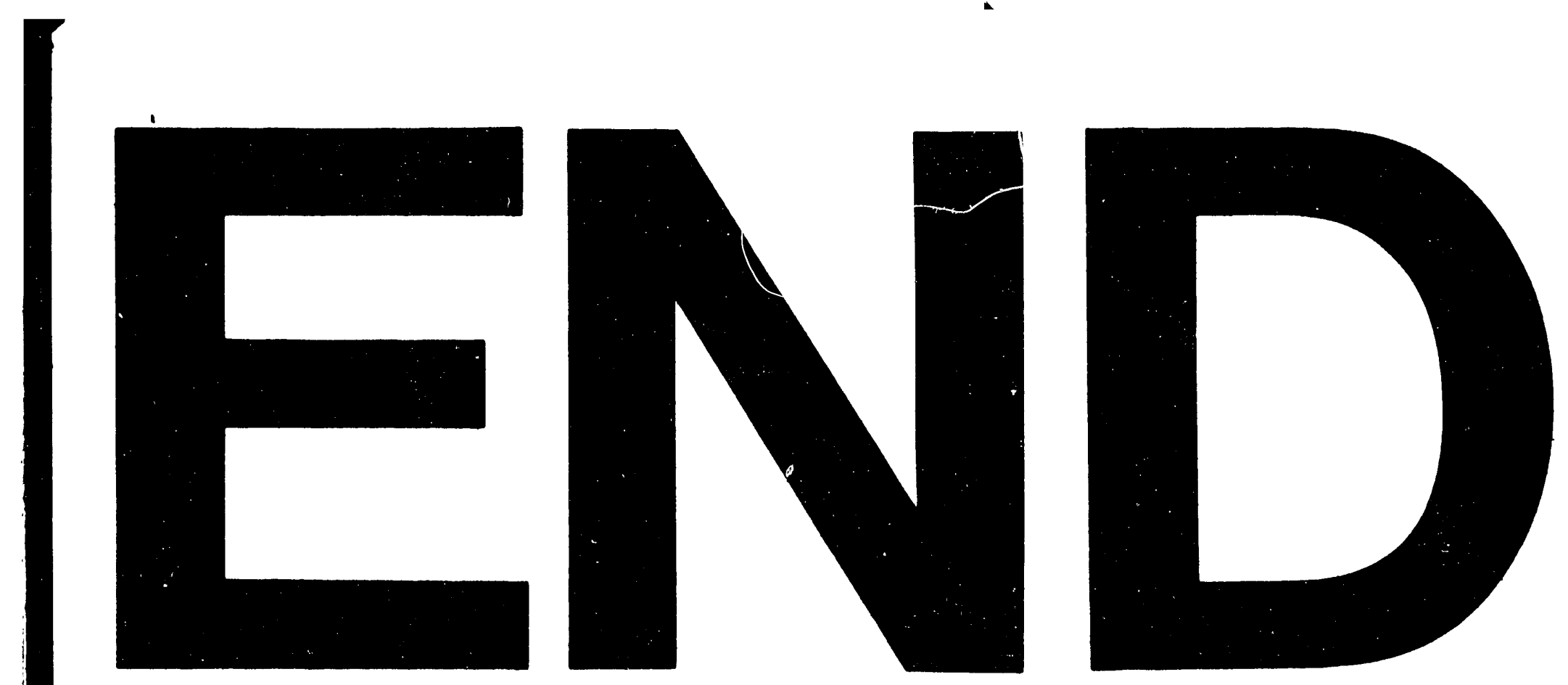

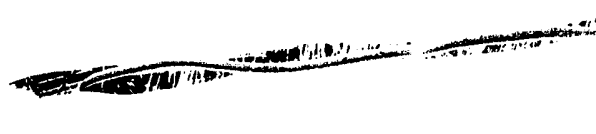
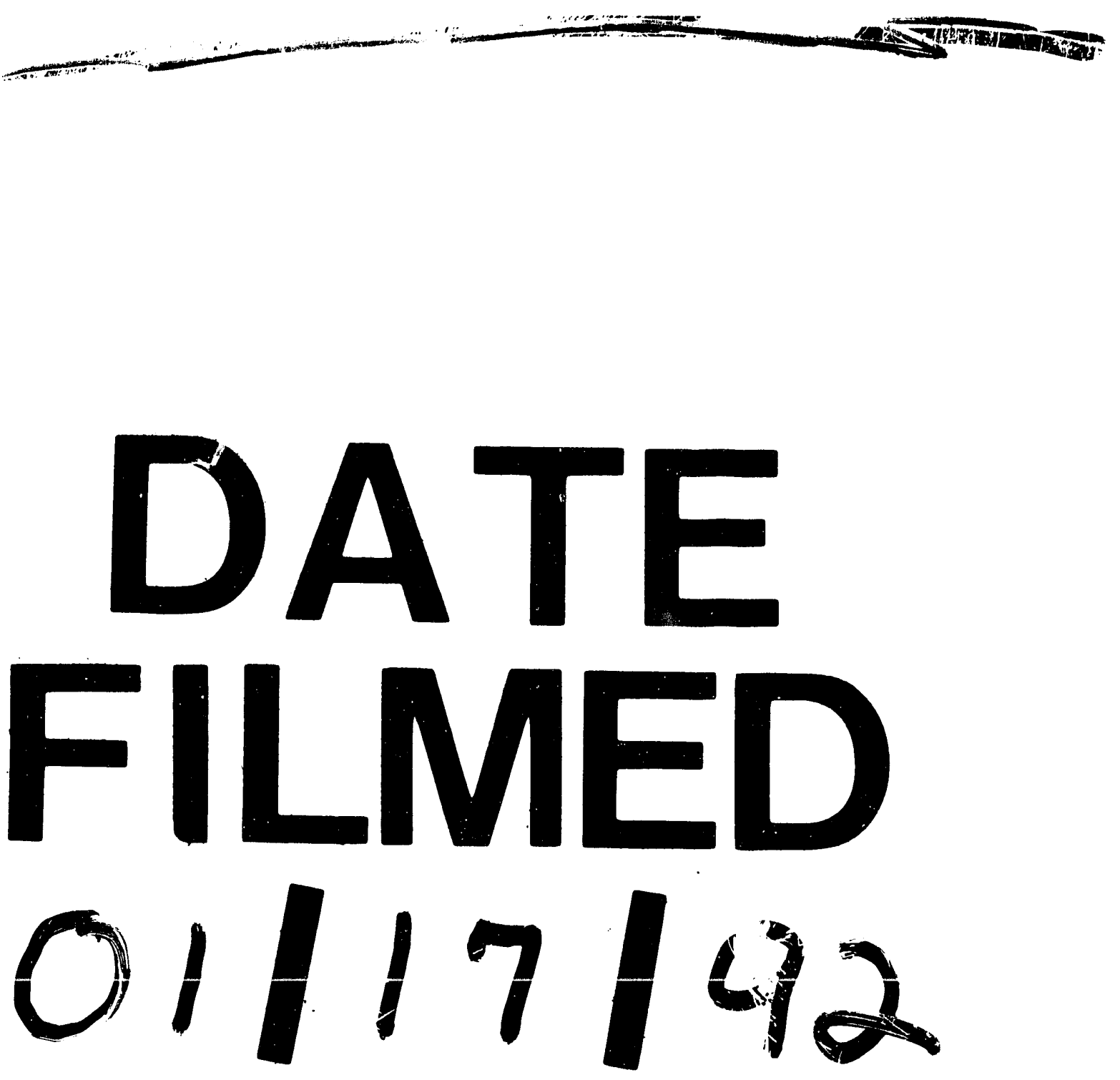


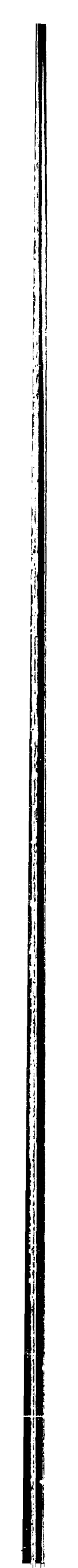

